\title{
Evaluation of estrogenic potential by herbal formula, HPC 03 for in vitro and in vivo
}

\author{
Bo Yoon Chang ${ }^{1}$, Dae Sung Kim², Hye Soo Kim² and Sung Yeon Kim ${ }^{1}$ \\ ${ }^{1}$ Institute of Pharmaceutical Research and Development, College of Pharmacy, Wonkwang University, Iksan, \\ Jeonbuk, South Korea and ${ }^{2}$ Hanpoong Pharm. Co. Ltd, Jeonju-si, Jeonbuk, South Korea \\ Correspondence should be addressed to S Y Kim; Email: sungykim@wonkwang.ac.kr
}

\begin{abstract}
HPC 03 is herbal formula that consists of extracts from Angelica gigas, Cnidium officinale Makino and Cinnamomum cassia Presl. The present study evaluated the estrogenic potential of HPC 03 by using in vitro and in vivo models. The regulatory mechanisms of HPC 03 in estrogen-dependent MCF-7 cells were assessed. HPC 03 induced the proliferation of estrogen receptor-positive MCF-7 cells, and the proliferation was blocked by the addition of the estrogen antagonist tamoxifen. The estrogen receptor $\alpha / \beta$ luciferase activities were significantly increased by HPC 03 treatment, which also increased the mRNA expression of the estrogen-responsive genes Psen2, Pgr and Ctsd. Also, we evaluated the ameliorative effects of HPC 03 on menopausal symptoms in ovariectomized rats. HPC 03 treatment in OVX rats significantly affected the uterine weight, increased the expression of estrogen-responsive genes Pgr and Psen2 in uterus, increased bone mineral density loss in the femur and inhibited body weight increase. Serum E2, collagen type 1 and osteocalcin were significantly increased, while serum LH, FSH and ALP were decreased compared with OVX rats. HPC 03 may be a promising candidate for the treatment of menopause, but further research is necessary to determine whether the observed effects also occur in humans.

Reproduction (2018) 155 103-113
\end{abstract}

\section{Introduction}

Postmenopausal women experience estrogen deficiencyrelated menopausal symptoms, which include hot flashes, mood swings and sweating and exhibit a dramatic increase in the risk of metabolic syndrome, cognitive deficits, cardiovascular disease, dyslipidemia and osteoporosis. As the general population ages and life expectancy increases, the importance of preventing and/or improving menopause-related changes has become paramount (Hill et al. 2016, Roberts \& Hickey 2016, Zhu et al. 2016).

Hormone replacement therapy (HRT) is widely used for the treatment of menopause symptoms and osteoporosis after menopause. Although HRT may lower the rates of osteoporosis and fracture, large-scale clinical research has shown that HRT is a factor in the growth of ovarian cancer and the increased incidence of breast cancer, cardiovascular disease and stroke (Anagnostis et al. 2016, Hill et al. 2016). Therefore, increased interest in complementary therapies using natural products, which have good effectiveness and fewer side effects, has arisen from both patients and physicians (Taylor 2015, Zhu et al. 2016).

Phytoestrogens, the name given to plant-derived estrogens, occur naturally in a diverse range of foods and include isoflavones, lignans, coumestans and flavonoids (e.g. quercetin and kaempferol). As the structure of phytoestrogens is similar to that of human estrogen, phytoestrogens can bind to estrogen receptors (ERs). Many researchers have searched for additional phytoestrogens that show estrogen-like activity, which has led to the continuous discovery of novel phytoestrogens in nature (Dittfeld et al. 2015, Franco et al. 2016).

Various plants have traditionally been used to treat menopausal patients. Some herbal plants, such as Actaea racemosa, Caulerpa racemosa, Angelica sinensis, Angelica gigas, Panax ginseng, Piper methysticum and Oenothera biennis, have a potent effect on menopausal symptoms (Huntley \& Ernst 2003, Borrelli \& Ernst 2008, Ross 2014, Franco et al. 2016). A reduction in hot flashes serves as a good indicator of the hormonal activity of these herbs, and there is increasing evidence that they confer a variety of protective effects on the body, such as an anti-osteoporotic effect. To develop a herbal medicine-derived remedy for the treatment of menopausal symptoms and osteoporosis after menopause, we surveyed the list of medicinal plants traditionally used in clinical practice and conducted an experimental screening, which focused on the regulation of ER-mediated proliferation, using the human breast cancer cell line MCF7. Finally, we selected a formula, HPC 03 that consisted of three herbal plants: Angelica 
gigas, Cnidium officinale Makino and Cinnamomum cassia Presl.

A. gigas (Umbelliferae) root has been traditionally used in Korean folk medicine as a female balancing agent and a panacea for gynecologic complaints. $A$. gigas has been reported to exert estrogenic effects in ovariectomized rats (Choi et al. 2012). Angelica spp. is not used alone in Chinese medicine formulations, but must be given in concert with other botanicals to promote the synergies needed for therapeutic effects (Huntley \& Ernst 2003, Chang et al. 2012, Choi et al. 2012). C. officinale Makino has been used in Asia for centuries as a medicinal plant for the treatment of pain and inflammation (Lee et al. 2013, 2016b). C. officinale contains a variety of volatile phthalide derivatives (Leon et al. 2017). Ferulic acid is one of the major compounds found in C. officinale. Recent reports have suggested that various phytochemicals with antioxidant and anti-inflammatory properties, such as ferulic acid, confer bone protective effects and suppress bone resorption, which results in increased bone strength (de la Cruz et al. 2014, Sagar et al. 2016). C. cassia Presl. (Lauraceae) is widely cultivated in China: the dry bark has been regarded as a folk medicine and a food spice in daily diet. The total polyphenolic contents (cinnamic, flavonic and anthocyanic derivatives) are found in the extract of $C$. cassia. All the aforementioned compounds are polyphenols, which have antioxidant, antiproliferative and antiangiogenic biological activities. Some of these compounds displayed weak estrogenic activity, which may confer a protective effect against breast cancer (Asif 2012, Sun et al. 2016).

The purpose of this study was to assess the estrogenic activity of HPC 03 by using various in vitro assays. We also treated OVX rats, which exhibit most of the characteristics of human menopausal symptoms, with HPC 03 for 12 weeks and then assessed the metabolic parameters related to menopausal symptoms.

\section{Materials and methods}

\section{Plant material and extraction}

The dried fruits of A. gigas, C. officinale Makino and C. cassia Presl were purchased from the local herbal market in Jeonbuk, Korea. The herbs were identified and authenticated by Dr Hyoung-Kwon Cho of the Hanpoong Pharm. Co. Ltd, where the voucher specimens (\#HPS-23, HPS-20, HPS-78) were deposited. The herb materials were identified and tested for harmful substance (pesticides: $\mathrm{BCH}$, Aldrin, Dieldrin, Endrin, DDT: heavy metals: $\mathrm{Pb}, \mathrm{As}, \mathrm{Hg}, \mathrm{Cd}$ ) by Hanpoong Pharm \& Food (Jeonju, Korea). The three herbs were mixed in a 2:1:1 (w/w) ratio of A. gigas:C. officinale Makino:C. cassia Presl. The mixture was extracted with a tenfold volume of $30 \%$ ethanol for $3 \mathrm{~h}$ at $80^{\circ} \mathrm{C}$. The solvent was removed under reduced pressure in a rotary evaporator ( $\mathrm{N}-1000 \mathrm{~S}, \mathrm{EYELA}$, Japan) to yield the extract $(26.67 \%, \mathrm{w} / \mathrm{w})$. The extracted powder was used for the preparation of HPC 03. The content of the markers decursin, ferulic acid or cinnamic acid in HPC 03 was quantitated using high-performance liquid chromatography (HPLC).

\section{HPLC analysis of HPC 03}

The quality of HPC 03 was controlled by monitoring the amounts of decursin, ferulic acid or cinnamic acid, which were marker compounds of $A$. gigas, $C$. officinale Makino and C. cassia Presl., respectively. HPC 03 was used for further experiments only when the concentrations of decursin (including decursinol angelate), ferulic acid or cinnamic acid were $107.4 \pm 0.91,0.82 \pm 0.01$, and $0.29 \pm 0.05 \mathrm{mg} / \mathrm{g}$, respectively (Table 1). For HPLC analysis, HPC 03 powder $(0.5 \mathrm{~g})$ was hydrolyzed in $1 \mathrm{M} \mathrm{HCl}$ in water $(20 \mathrm{~mL})$. The hydrolysis was performed in triplicate. The acid-hydrolyzed sample was refluxed at $100^{\circ} \mathrm{C}$ for $1 \mathrm{~h}$, cooled to room temperature $\left(20^{\circ} \mathrm{C}\right)$, diluted to $200 \mathrm{~mL}$ and sonicated for $5 \mathrm{~min}$. The extract was filtered through a $0.45 \mu \mathrm{m}$ filter prior to injection into a Waters HPLC system (Waters, Milford, MA, USA), which comprised a Waters 1525 pump, a 2707 autosampler and a 2998 PDA detector. The chromatic separation was achieved at $35^{\circ} \mathrm{C}$ on a Waters Sunfire $\mathrm{C} 18$ column $(250 \mathrm{~mm} \times 4.6 \mathrm{~mm}$ I.D., $5 \mu \mathrm{m}$ particle size $)$. The flow rate was $1.0 \mathrm{~mL} / \mathrm{min}$ and the injection volume was $10 \mu \mathrm{L}$. The sample was injected twice to analyze each marker compound, and the eluents from the column were monitored at $330 \mathrm{~nm}$ for decursin, $320 \mathrm{~nm}$ for ferulic acid and $280 \mathrm{~nm}$ for cinnamic acid. The HPLC chromatogram of HPC 03 is given in Fig. 1.

\section{Cell culture}

MCF-7, an ER-positive human breast cancer cell line, was purchased from American Type Culture Collection (ATCC) and cultured in DMEM medium supplemented with $10 \%$ fetal bovine serum and penicillin-streptomycin solution (100 units/mL penicillin and $100 \mu \mathrm{g} / \mathrm{mL}$ streptomycin: Hyclone Laboratories Inc., South Logan, UT, USA). The cells were grown at $37^{\circ} \mathrm{C}$ in a humidified atmosphere of $95 \%$ air $/ 5 \%$ $\mathrm{CO}_{2}$. The medium was renewed 2-3 times per week, and

Table 1 Effects of HPC 03 on alkaline phosphate (ALP), bone alkaline phosphate (BALP), collagen type 1 (CTx) and osteocalcin (OC) in OVX rats.

\begin{tabular}{|c|c|c|c|c|c|c|}
\hline \multirow[b]{2}{*}{ Factor } & \multirow[b]{2}{*}{ SHAM } & \multirow[b]{2}{*}{ OVX } & \multirow[b]{2}{*}{$\mathrm{OVX}+\mathrm{E} 2$} & \multicolumn{3}{|c|}{ OVX + HPC 03} \\
\hline & & & & $50 \mathrm{mg} / \mathrm{kg}$ & $100 \mathrm{mg} / \mathrm{kg}$ & $200 \mathrm{mg} / \mathrm{kg}$ \\
\hline $\mathrm{ALP}(\mathrm{U} / \mathrm{L})$ & $46.5 \pm 4.0^{\mathrm{a}}$ & $89.3 \pm 4.1^{b}$ & $50.0 \pm 0.9^{a}$ & $82.3 \pm 1.2^{b}$ & $72.3 \pm 1.2^{\mathrm{c}}$ & $63.0 \pm 4.1^{c}$ \\
\hline $\mathrm{BALP}(\mathrm{U} / \mathrm{L})$ & $102.0 \pm 8.1^{\mathrm{a}}$ & $156.3 \pm 10.9^{b}$ & $98.2 \pm 5.2^{\mathrm{a}}$ & $148.2 \pm 4.2^{b}$ & $123.3 \pm 8.3^{c}$ & $117.5 \pm 2.3^{c}$ \\
\hline $\mathrm{CT}_{\mathrm{X}}(\mathrm{pg} / \mathrm{mL})$ & $80.1 \pm 2.1^{\mathrm{a}}$ & $120.4 \pm 6.0^{\mathrm{b}}$ & $92.4 \pm 2.5^{* *}$ & $118.9 \pm 4.0^{\mathrm{b}}$ & $107.9 \pm 3.8^{c}$ & $105.8 \pm 3.1^{\mathrm{c}}$ \\
\hline $\mathrm{OC}(\mathrm{pg} / \mathrm{mL})$ & $62.1 \pm 3.5^{a}$ & $87.6 \pm 1.2^{b}$ & $65.3 \pm 4.0^{\mathrm{a}}$ & $82.0 \pm 3.9^{b}$ & $75.3 \pm 2.2^{b}$ & $71.9 \pm 5.2^{\mathrm{c}}$ \\
\hline
\end{tabular}

Serum levels of ALP, BALP, CTx and OC were measured at the end of the treatment period. Values with different letters (a, b, c) are significantly different one from another (one-way ANOVA followed by Newman-Keuls multiple range test, $P<0.05$ ). 

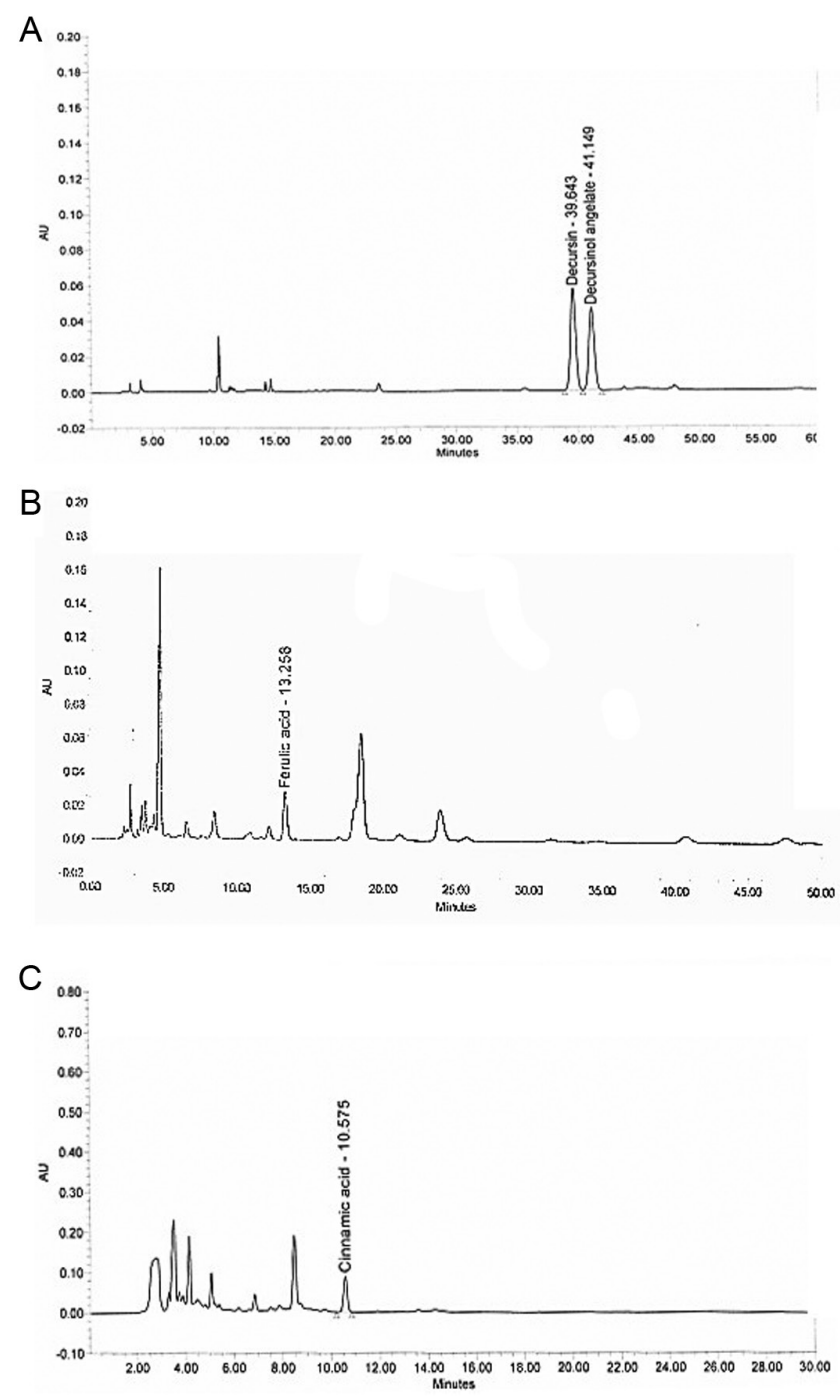

Figure 1 HPLC chromatograms showing peaks corresponding to the marker compounds of HPC 03.

before reaching confluence, the cells were subcultured every $3-4$ days in a 1:4 ratio.

\section{Proliferation assay of MCF-7 cells (E-screen assay)}

Confluent MCF-7 cells were washed twice with phosphatebuffered saline (PBS) (Hyclone Laboratories) and 0.05\% trypsin-EDTA solution (Invitrogen) was added for $1 \mathrm{~min}$. After trypsin-EDTA was removed, the culture was left at room temperature for 5-10 min: subsequently, the cells were detached, resuspended in DMEM medium, counted and seeded into 96-well plates at a density of $2 \times 10^{4}$ cells/ well. After $24 \mathrm{~h}$, the cells were completely attached to the well bottom: the medium was then aspirated and estrogenfree medium containing both phenol-red-free DMEM (Invitrogen) and 5\% charcoal-dextran-stripped human serum (Hyclone Laboratories) was added. MCF-7 cells were treated with different concentrations of HPC 03 and were cultured for $24 \mathrm{~h}$. In addition, HPC 03 was added to the medium at concentrations at which it showed estrogenic activity, either with or without the ER-antagonist tamoxifen (Sigma-Aldrich). $17 \beta$-Estradiol and PBS were used as the positive and negative controls, respectively.

\section{MTT proliferation assay}

Cell proliferation was assessed using the MTT assay on cells which had been cultured for $24 \mathrm{~h}$. After an incubation period, $100 \mu \mathrm{L}$ of $5 \mathrm{mg} / \mathrm{mL}$ thiazolyl blue tetrazolium bromide (Sigma) solution was added to cells in each well and cells were incubated further for $4 \mathrm{~h}$ in a humidified atmosphere at $37^{\circ} \mathrm{C}$ in an atmosphere of $5 \% \mathrm{CO}_{2}$. The medium was replaced with $1 \mathrm{~mL}$ dimethyl sulfoxide. The absorbance was measured at $540 \mathrm{~nm}$ by using a microplate reader (Molecular Devices Inc., Sunnyvale, CA, USA), and the cell proliferation values were expressed as a percentage compared with the negative control, which was considered to represent $100 \%$ cell proliferation.

\section{ER reporter assays}

To assess the activation of human $\mathrm{ER}_{\alpha / \beta}$, nuclear receptor reporter assays were performed (Indigo Biosciences, State College, PA, USA). HPC 03 were prepared and diluted in medium provided by the manufacturer. The cell recovery medium provided in the assay kit was thawed, warmed to $37^{\circ} \mathrm{C}$ and added to the tube of frozen reporter cells. The cell suspension $(100 \mu \mathrm{L})$ was dispensed into the wells of a 96-well assay plate and incubated for $4 \mathrm{~h}$ to allow the cells to attach. HPC $03(100 \mu \mathrm{L})$ was added to the cells at the indicated concentrations and incubated for $24 \mathrm{~h}$. Luciferase activity was quantified using a BioTek Synergy plate reader (Biotek Instruments, Winooski, VT, USA).

\section{Gene expression analysis}

Prior to reverse transcription polymerase chain reaction (RT-PCR), total RNA was extracted using a total RNA extraction kit (easy-BLUE, iNtRON Biotechnology, Korea). The RNA isolation protocol included a DNase I treatment step. RNA samples were quantified by the measurement of the optical density at $260 \mathrm{~nm}$. All reaction mixtures contained approximately $100 \mathrm{ng}$ RNA in a reaction volume of $25 \mu \mathrm{L}$. The primer and probe concentrations were $300 \mathrm{nM}$ and $200 \mathrm{nM}$, respectively. The conditions used for real-time quantitative RT-PCR were as follows: $30 \mathrm{~min}$ at $48^{\circ} \mathrm{C}$ (RT, inactivation), $10 \mathrm{~min}$ at $95^{\circ} \mathrm{C}$ (initial activation) and then 40 cycles of amplification for $15 \mathrm{~s}$ at $95^{\circ} \mathrm{C}$ (denaturation) and $1 \mathrm{~min}$ at $60^{\circ} \mathrm{C}$ (annealing and extension). The following TaqMan Gene Expression Assays (Applied Biosystems) were used as the primers and probes for amplification: Psen2 (Hs01577197_ $\mathrm{m} 1), \operatorname{Pgr}$ (Hs015456702_m1), Ctsd (Hs00157205_m1) and Gapdh (Hs02786624_g1). Data analysis was performed with SDS 2.1.1 software, gene expression levels were normalized to the expression of the Gapdh housekeeping gene and relative expression level and PCR efficiency were evaluated (Pfaffl 2001). 


\section{Animals}

Six-week-old female Sprague-Dawley (SD) rats were purchased from Orientbio (Gyeonggi-do, Korea). The animals were housed in the following conditions: two rats per cage, airconditioned room at $23 \pm 1^{\circ} \mathrm{C}$ and $55-60 \%$ relative humidity, 12-h light/dark cycle and were fed an AIN 76A diet. After a 1 -week acclimatization period, 7 -week-old female SD rats were anesthetized with $2 \%$ isoflurane and the ovaries were removed bilaterally. SHAM surgery ligation and excision of a piece of adipose tissue of the same size was performed near the ovary and was medicated separately. The study was approved by the Wonkwang University Animal Care Committee (WKU16-06). We performed a pilot study with reference to previously published studies to determine the optimal sample size (Choi et al. 2012, Zhao et al. 2013, Zhang et al. 2016, Takakura et al. 2017). The pilot study was conducted on groups of SHAM, OVX, OVX+E2 (positive control) and OVX + HPC 03 (200 mg/kg/day) rats for 12 weeks. After killing, the BMD and hormone levels of the OVX $+E 2$ and OVX + HPC 03 groups were determined, which were significantly higher than those of the OVX group. In the present study, we chose to use five animals per group, which was the minimal number of experimental animals that could demonstrate significant differences in the pilot study.

\section{Animal experiment protocol}

After an adaptation period of 6 weeks, the rats were divided into six groups SHAM (sham-operated control), OVX (ovariectomized, but untreated), OVX+HPC 03 (ovariectomized rats administered 50, 100 and $200 \mathrm{mg} / \mathrm{kg}$ / day HPC 03, respectively) and OVX +E2 (ovariectomized rats administered $10 \mu \mathrm{g} / \mathrm{kg}$ estradiol). All rats were fed daily by gavage for 12 consecutive weeks. The body weight of each rat was measured once a week until the final day of administration. On the last day of the study, serum samples were collected from abdominal aortic artery and stored at $-70^{\circ} \mathrm{C}$ until examination. The uteruses were dissected out and immediately weighed.

\section{Bone density}

After anesthetization with ketamine and xylazine $(100 \mathrm{mg} / \mathrm{kg}$ body weight and $10 \mathrm{mg} / \mathrm{kg}$ body weight, respectively), the bone mass density (BMD) of the right femur were measured using a dual-energy X-ray absorptiometer (DEXA: InAlyzer, Medikors, Seungnam, Korea), which was equipped with the appropriate software for the assessment of bone density in small animals.

\section{Hormone assay}

Blood samples were collected from each rat before killing. To separate serum, blood was kept at $4^{\circ} \mathrm{C}$ for $1 \mathrm{~h}$, followed by centrifugations for $300 \mathrm{~min}$ at $15,000 \mathrm{~g}$ at $4^{\circ} \mathrm{C}$. Serum was kept at $-80^{\circ} \mathrm{C}$ until hormonal assay was performed. The serum estradiol (E2), luteinizing hormone (LH) and folliclestimulating hormone ( $\mathrm{FSH}$ ) concentrations were determined by indirect ELISA method. The kits used for the experiments included Estradiol Kit (Enzo Life Sciences, Inc. NY, USA: minimum detectable concentration $(\operatorname{minDC})=14 \mathrm{pg} / \mathrm{mL}), \mathrm{LH}$ (Antibodies-Online, Atlanta, GA, USA: $\operatorname{minDC}=98.77 \mathrm{pg} /$ $\mathrm{mL}$ ) and $\mathrm{FSH}$ kits (Antibodies-Online, $\operatorname{minDC}=2.47 \mathrm{ng}$ / $\mathrm{mL}$ ). All experiments were performed in accordance with the manufacturer's instructions (Shelton et al. 2013, SewaniRusike et al. 2016, Tomaz et al. 2016). Serum samples were added to the appropriate micro ELISA plate wells and combined with the specific antibody. A biotinylated detection antibody specific to E2 and avidin-horseradish peroxidase (HRP) conjugate was then added to each microplate well successively and incubated. Free components were washed away. The substrate solution was added to each well. Only the wells that contained E2, biotinylated detection antibody and avidin-HRP conjugate appeared blue in color. The enzymesubstrate reaction was terminated by the addition of a sulfuric acid solution, and the color turned yellow. The optical density (OD) was measured spectrophotometrically at a wavelength of $450 \mathrm{~nm}$. The OD value was proportional to the concentration of E2. The concentration of serum E2 $(\mathrm{pg} / \mathrm{mL}), \mathrm{LH}(\mathrm{pg} / \mathrm{mL})$ and $\mathrm{FSH}(\mathrm{ng} / \mathrm{mL})$ was then calculated using kit provided standards. $\mathrm{LH}$ and $\mathrm{FSH}$ measurement were performed in a similar manner using a different ELISA kit.

\section{Biochemical markers of bone}

Serum levels of total alkaline phosphatase (ALP), bone-specific ALP (BALP) activities, osteocalcin (OC) and C-telopeptide of type I collagen (CTX-I) were measured using sandwich ELISA kits (ALP: Kamiya Biomedical Company, Tukwila, WA, USA. $\operatorname{minDC}=1.24 \mathrm{U} / \mathrm{Lpg} / \mathrm{mL}$; BALP: Cusabio Biotech, MD, USA. $\operatorname{minDC}=3.9 \mathrm{U} / \mathrm{L} \mathrm{pg} / \mathrm{mL} ; \quad O C$ : LifeSpan Biosciences, Inc., Seattle, WA, USA. $\operatorname{minDC}=15.63 \mathrm{pg} / \mathrm{mL}$; CTX-I: Cusabio Biotech, Baltimore MD, USA. minDC $=31.25 \mathrm{pg} /$ $\mathrm{mL}$ ). All experiments were performed in accordance with the manufacturer's instructions (Chen et al. 2014, Conte Neto et al. 2014, Wei et al. 2014). Capture antibody were coated onto the wells of microplates. Samples, including a standard containing protein, were pipetted into these wells. During the first incubation, the protein antigen binds to the capture antibody. After washing, a detection antibody is added to the wells, and this antibody binds to the immobilized protein captured during the first incubation. After removal of excess detection antibody, an HRP conjugate was added and bound to the detection antibody. After a third incubation and washing to remove the excess HRP conjugate, a substrate solution is added and is converted by the enzyme to a detectable form. The optical density (OD) was measured spectrophotometrically at a wavelength of $450 \mathrm{~nm}$. The concentrations of ALP, BALP, OC and CTX-I in the samples were calculated by comparing the OD of the samples with the standard curve.

\section{Statistical analysis}

Data were expressed as mean \pm S.D. Significant differences were compared using repeated measures ANOVA followed by the Newman-Keuls multiple range test. Statistical significance was defined as $P<0.05$. All statistical analyses were performed using GraphPad Software. 


\section{Results}

\section{Effects of HPC 03 on ER-mediated cell proliferation}

The proliferative effects of HPC 03 were evaluated relative to negative control cells. E2, which significantly stimulated proliferation of ER-positive MCF-7 cells, was used as the positive control. HPC $03(25-100 \mu \mathrm{g} /$ $\mathrm{mL}$ ) also stimulated MCF-7 proliferation, the maximum effect $(131 \%)$, which was equivalent to the proliferative effect of $0.1 \mathrm{nM}$ E2 in this cell line, was observed at a concentration of $50 \mu \mathrm{g} / \mathrm{mL}$ HPC 03 and E2-induced proliferation was blocked by $6.4 \mu \mathrm{M}$ tamoxifen (Fig. 2).

\section{Effects of HPC 03-induced $E R_{\alpha / \beta}$-mediated luciferase activity}

HPC 03 exhibited estrogenic activity in human ER $\alpha$ reporter assays at $25-100 \mu \mathrm{g} / \mathrm{mL}(P<0.01)$ (Fig. $3 \mathrm{~A})$ and human ER $\beta$ reporter assays at $50-100 \mu \mathrm{g} / \mathrm{mL}(P<0.01)$ (Fig. 3B), which indicated that these effects were ER mediated.

\section{Effects of HPC 03 on the mRNA levels of estrogen- dependent genes in cell in OVX rats}

Three estrogen-dependent genes (Psen2, Pgr and Ctsd) in MCF7 cells were selected for the investigation of the HPC 03-induced transcriptional response through ER binding. Real-time PCR analysis showed that the mRNA levels of Psen2, Pgr and Ctsd were significantly increased under these conditions. Estrogen-dependent genes expression induced by HPC 03 and E2 was blocked by addition of tamoxifen indicating an ER-dependent

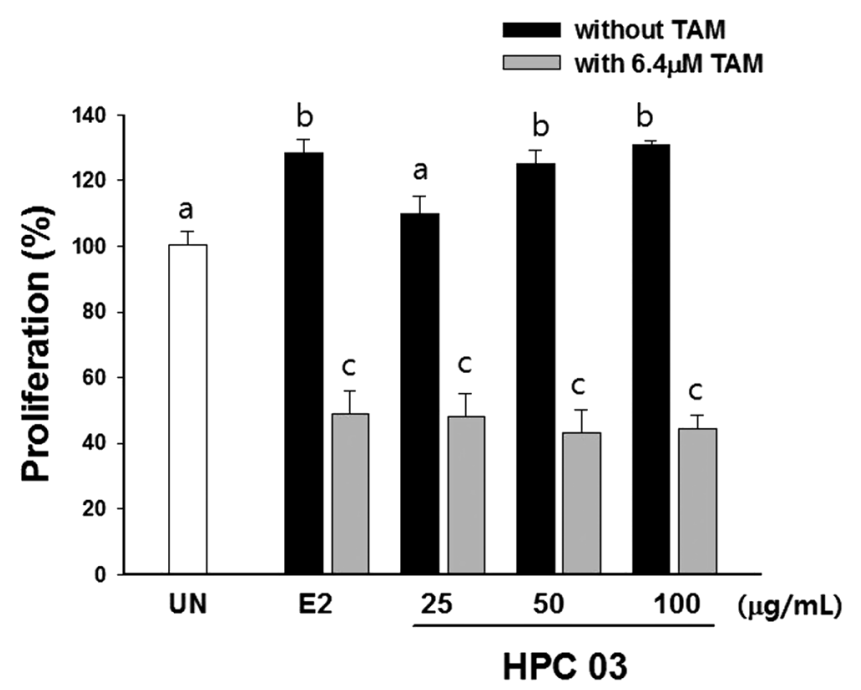

Figure 2 Effects of HPC 03 on MCF-7 cell proliferation. Tamoxifen was used as an estrogen antagonist. The results are presented as the mean \pm S.D. Values with different letters $(\mathrm{a}, \mathrm{b}, \mathrm{c})$ are significantly different one from another (one-way ANOVA followed by Newman-Keuls multiple range test, $P<0.05$ ). mechanism for the estrogenic effect on MCF-7 cell proliferation (Fig. 4).

\section{Effects of HPC 03 on body weight change and uterine weight in OVX rats}

No death occurred in any of the HPC 03 groups to the end of study, and no obvious clinical sign, including loss of fur, changes in skin color, scabbing, eyes and mucous membranes and change in behavior patterns were observed in any of the HPC 03 groups throughout the experimental period (data not shown). In all groups, body weight increased over time, but the increase was significantly more in the OVX group compared with the SHAM group. A significant difference in body weight was observed between the E2-treated group and the OVX group at 1 week after the start of administration (Fig. 5A). As expected, the body weight of
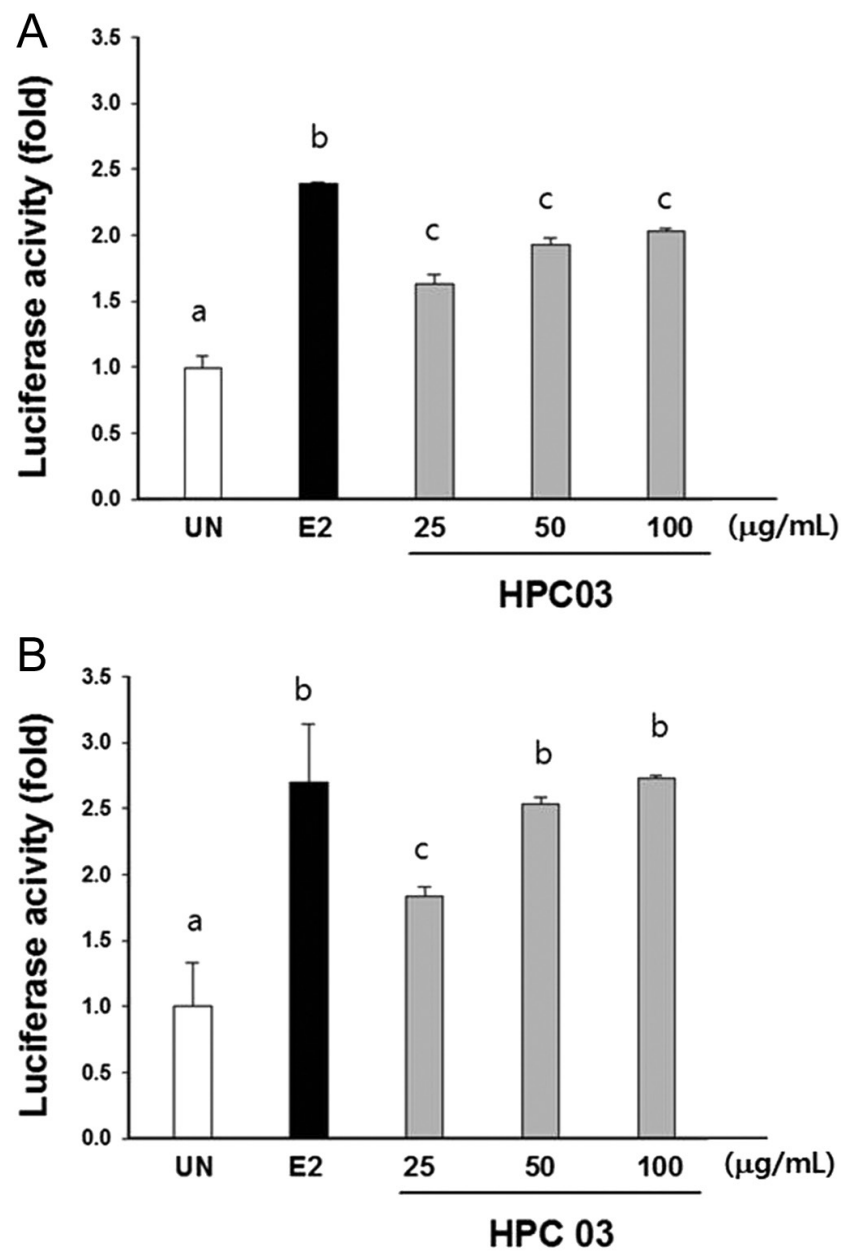

Figure 3 Effects of HPC 03-induced $\mathrm{ER}_{\alpha / \beta}$-mediated luciferase activity. (A) $E R_{\alpha}$ and (B) $E R_{\beta}$ reporter assays of cells treated with the indicated concentrations of HPC 03 for $24 \mathrm{~h}$. The results are presented as the mean \pm S.D. Values with different letters $(a, b, c)$ are significantly different one from another (one-way ANOVA followed by NewmanKeuls multiple range test, $P<0.05)$. 

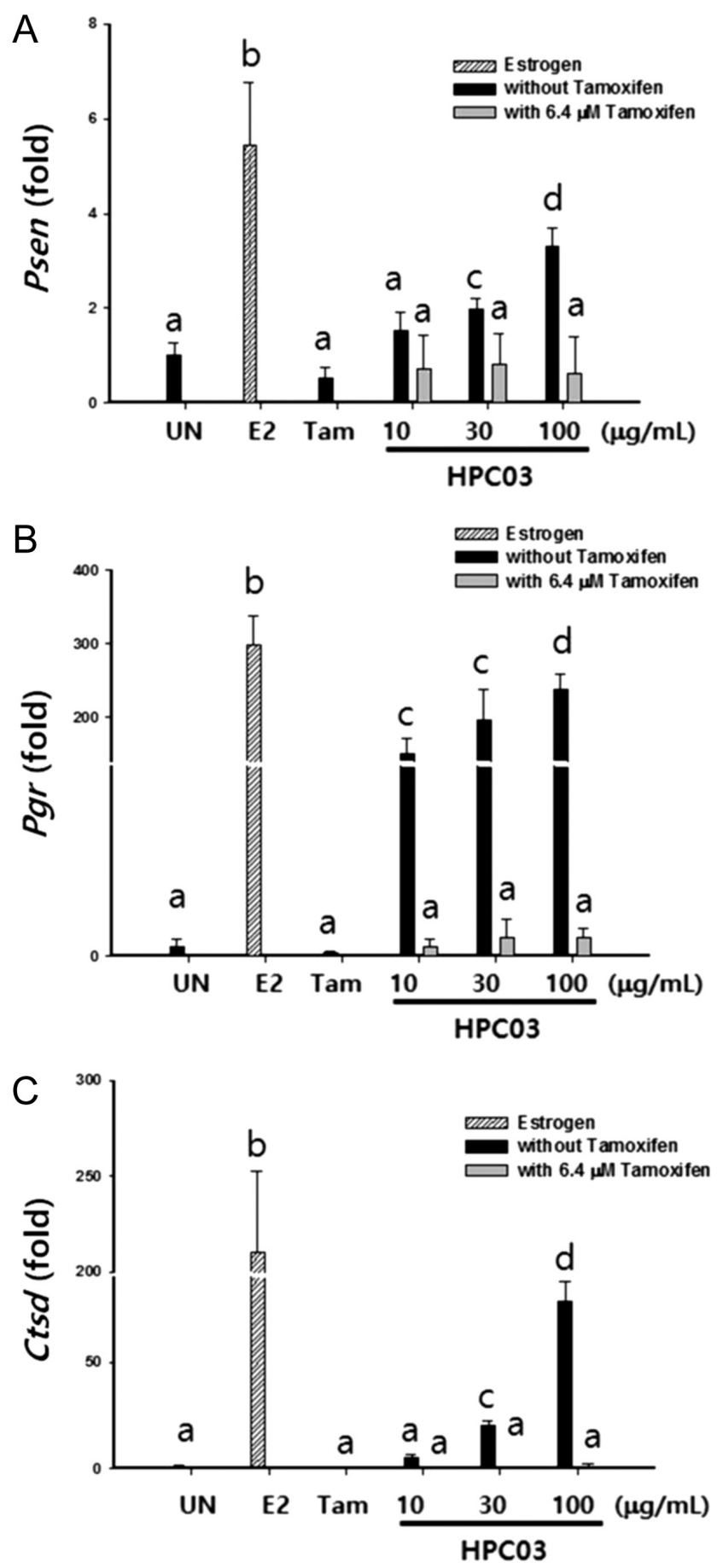

Figure 4 Effects of HPC 03 on the mRNA levels of estrogendependent genes. HPC 03 was added to the medium at 10-100 $\mu \mathrm{g} /$ $\mathrm{mL}$ where they measured estrogenic activity, either with or without the ER-agonist tamoxifen. mRNA levels of (A) Psen2, (B) Pgr and (C) $C t s d$ were quantified using real-time PCR. The results are presented as the mean \pm S.D. Values with different letters $(a, b, c, d)$ are significantly different from one another (one-way ANOVA followed by Newman-Keuls multiple range test, $P<0.05$ )

animals in the E2 group was significantly less than that of the OVX group. Furthermore, the body weight gain of
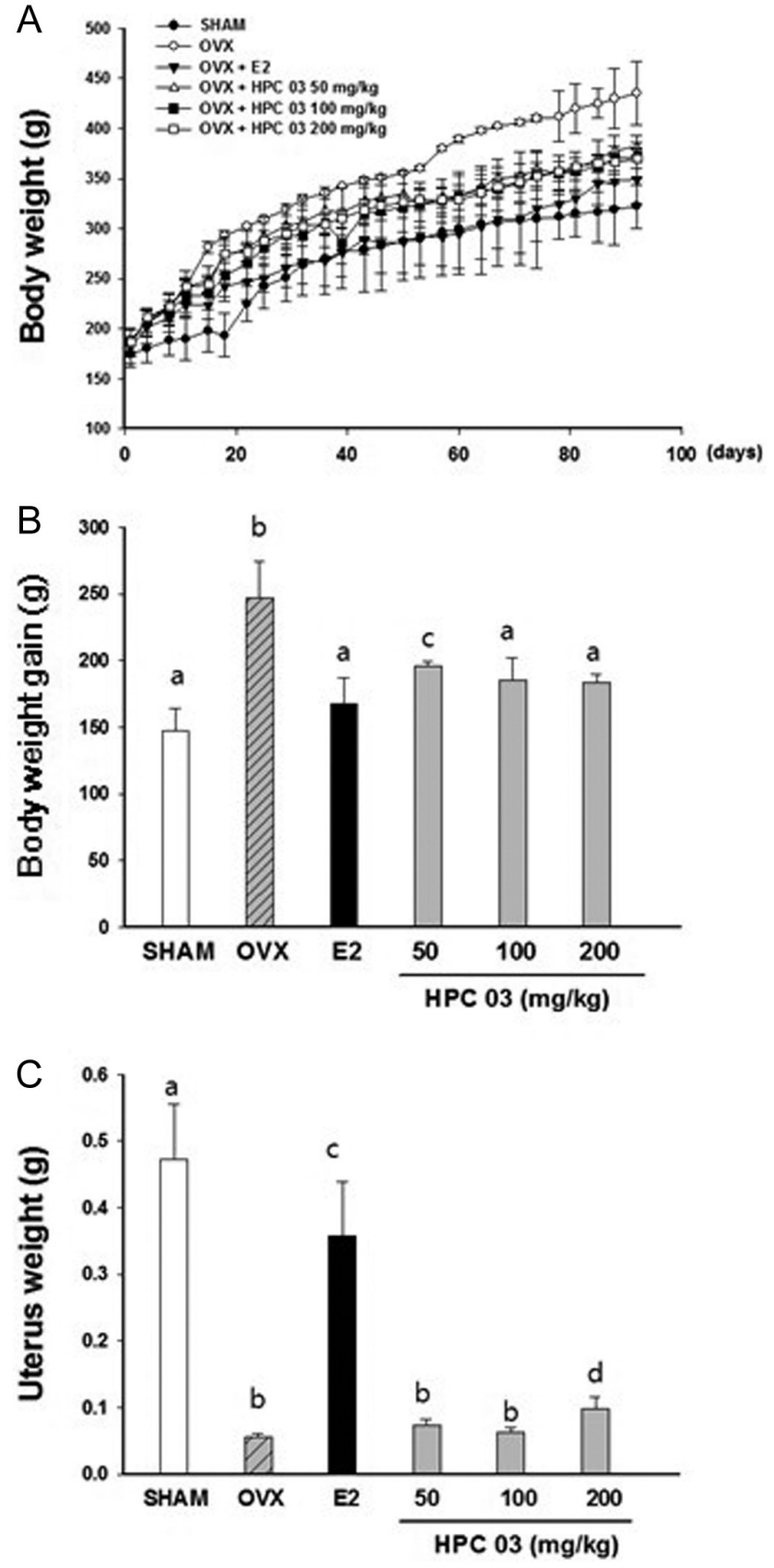

Figure 5 Effects of HPC 03 on the (A) body weight change, (B) body weight gain and $(C)$ uterine weight in OVX rats. During the experimental period, body weight was measured every 3 days. Body weight gain was calculated by the equation: final body weight initial body weight. The results are presented as the mean \pm S.D. Values with different letters $(a, b, c, d)$ are significantly different from one another (one-way ANOVA followed by Newman-Keuls multiple range test, $P<0.05)$.

animals in the HPC 03-treated group was significantly less than that of the OVX group (Fig. 5B). OVX caused atrophy of uterine tissue, which indicated the success of the surgical procedure in the E2 group, the uterine weight was significantly increased compared with the 
OVX group. In the group treated with $200 \mathrm{mg} / \mathrm{kg}$ HPC 03, a significant amelioration of the uterine weight decrease caused by the OVX operation was observed (Fig. 5C).

\section{Effects of HPC 03 on BMD in OVX rats}

At 3 weeks after the OVX operation, the OVX group showed a significant decrease in the femur BMD compared to the SHAM group (Fig. 6A). After 12 weeks of treatment, the final femur BMD of the $200 \mathrm{mg} /$
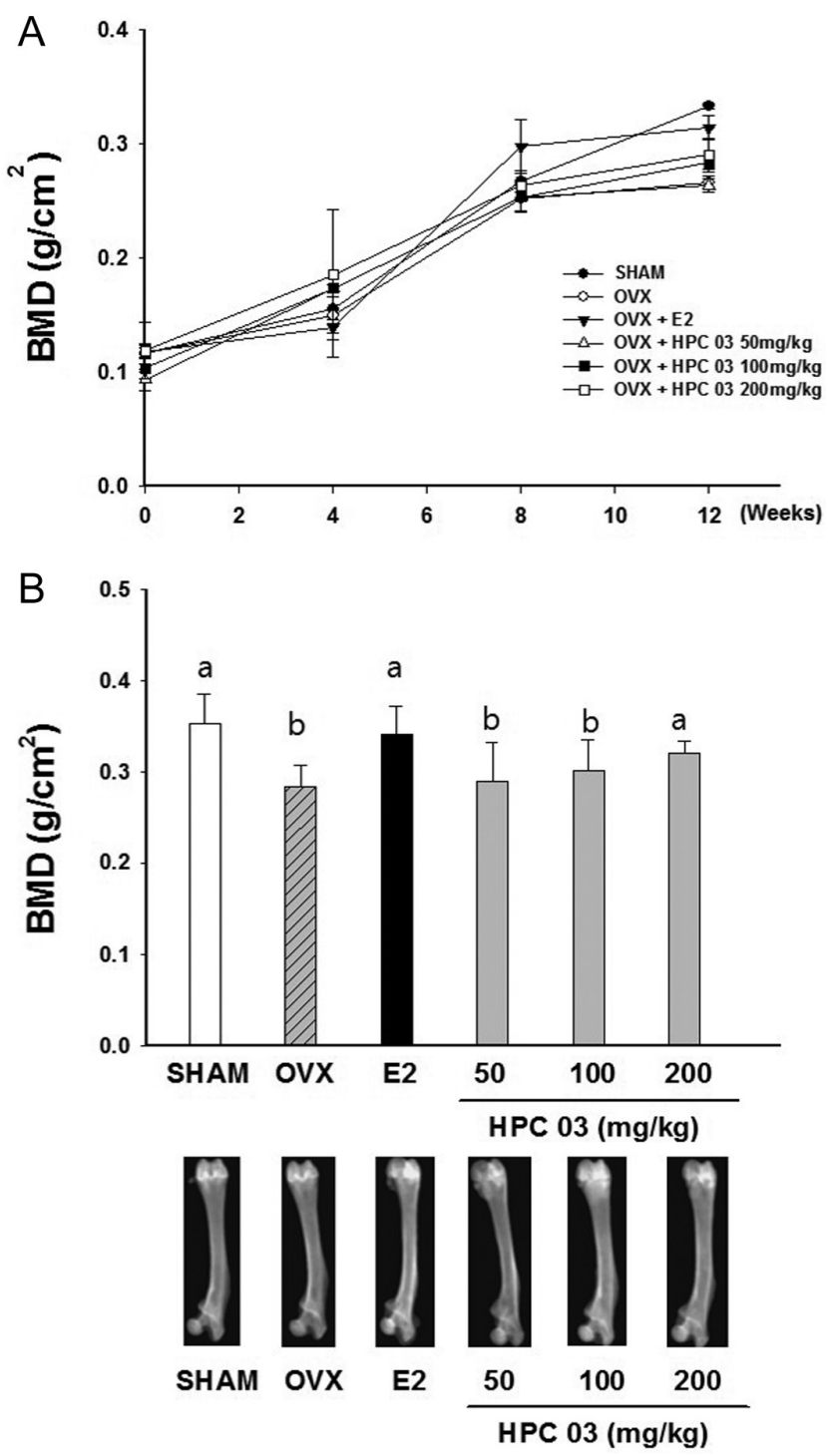

Figure 6 Effects of HPC 03 on (A) femur BMD change and (B) final femur BMD in OVX rats. During the experimental period, BMD was determined after anesthetization every 4 weeks. At the end of the treatment period, the femur was separated and the BMD was determined. The results are presented as the mean \pm S.D. Values with different letters $(a, b)$ are significantly different from one another (one-way ANOVA followed by Newman-Keuls multiple range test, $P<0.05)$. kg HPC 03-treated group $\left(0.3203 \pm 0.0031 \mathrm{~g} / \mathrm{cm}^{2}\right)$ was significantly higher than that of the OVX group $\left(0.2832 \pm 0.0210 \mathrm{~g} / \mathrm{cm}^{2}\right)$. HPC $03(200 \mathrm{mg} / \mathrm{kg})$ induced a $13 \%$ increase in the low femur BMD induced by OVX (Fig. 6B).

\section{Effects of HPC 03 on bone parameter in OVX rats}

Levels of ALP, BALP, CTX and OC in the OVX were significantly higher than the SHAM. After 12 weeks of treatment, the HPC 03 displayed significantly lower levels of ALP, BALP, CTx and OC compared with the OVX group. The observed decrease was stronger at higher doses of HPC 03: the highest dose $(200 \mathrm{mg} / \mathrm{kg})$ resulted in 29.4, 74.2, 12.1 and $17.9 \%$ decreases in ALP, BALP, CTx and OC levels (all $P<0.01$ ) compared with the OVX group, respectively (Table 1 ).

\section{Effects of HPC 03 on serum estrogen, $L H$ and FSH in OVX rats}

The OVX group was lower levels of serum E2 and higher levels of luteinizing hormone ( $\mathrm{LH})$ and follicle-stimulating hormone $(\mathrm{FSH})$ compared with the SHAM group. HPC 03 treatment at 50,100 or $200 \mathrm{mg} / \mathrm{kg}$ significantly raised the levels of circulating estrogen. HPC $03(200 \mathrm{mg} / \mathrm{kg})$ induced a 34\% increase in the estrogen level compared with that of OVX group, which was comparable to the SHAM group. HPC 03-treated group also had significant inhibitory effects on LH and FSH. The observed decrease was stronger at higher doses: the highest dose $(200 \mathrm{mg} /$ $\mathrm{kg}$ ) resulted in a decrease of $12.4 \%$ and $26.2 \%$ in $\mathrm{LH}$ and $\mathrm{FSH}$, respectively, (both $P<0.01$ ) compared with the untreated OVX group (Table 2).

\section{Effects of HPC 03 on the mRNA levels of estrogen- dependent genes in OVX rats}

The uterus of OVX group was lower expression of Psen2, Pgr and Ctsd compared with the uterus of SHAM group. HPC 03 treatment at $200 \mathrm{mg} / \mathrm{kg}$ significantly raised the expression of Psen2 and Pgr compared with the uterus of OVX group (Fig. 7A and B). However, no change in the Ctsd was observed with HPC 03-treated group in uterus of OVX group (Fig. 7C).

\section{Discussion}

Herbal formulas are widely used as complementary medicines. There is some dispute regarding the use of herbal formula because complex mixtures of medicinal herbs are employed in contrast to isolated single natural products. It is often suggested that herbal formula extracts work synergistically to increase the therapeutic effect while reducing the number of adverse side effects to healthy tissues (Huntley \& Ernst 2003, Hiruma et al. 2013, Satoh 2013). The present study has shown that 
Table 2 Effects of HPC 03 on serum estrogen, luteinizing hormone (LH) and follicle-stimulating hormone (FSH) in OVX rats.

\begin{tabular}{|c|c|c|c|c|c|c|}
\hline \multirow[b]{2}{*}{ Factor } & \multirow[b]{2}{*}{ SHAM } & \multirow[b]{2}{*}{ OVX } & \multirow[b]{2}{*}{$\mathrm{OVX}+\mathrm{E} 2$} & \multicolumn{3}{|c|}{ OVX + HPC 03} \\
\hline & & & & $50 \mathrm{mg} / \mathrm{kg}$ & $100 \mathrm{mg} / \mathrm{kg}$ & $200 \mathrm{mg} / \mathrm{kg}$ \\
\hline Estrogen $(\mathrm{pg} / \mathrm{mL})$ & $62.8 \pm 4.0^{\mathrm{a}}$ & $32.0 \pm 2.0^{b}$ & $70.0 \pm 4.0^{\mathrm{a}}$ & $42.5 \pm 4.5^{c}$ & $42.1 \pm 5.2^{c}$ & $55.0 \pm 3.0^{c}$ \\
\hline $\mathrm{LH}(\mathrm{pg} / \mathrm{mL})$ & $210.0 \pm 4.3^{\mathrm{a}}$ & $295.1 \pm 10.4^{b}$ & $245.2 \pm 4.2^{\mathrm{c}}$ & $290.4 \pm 5.0^{b}$ & $279.4 \pm 12.6^{b}$ & $258.3 \pm 10.8^{d}$ \\
\hline $\mathrm{FSH}(\mathrm{ng} / \mathrm{mL})$ & $65.2 \pm 3.4^{\mathrm{a}}$ & $109.8 \pm 7.0^{b}$ & $72.4 \pm 5.9^{c}$ & $102.5 \pm 6.2^{\mathrm{b}}$ & $98.4 \pm 6.2^{b}$ & $80.4 \pm 1.8^{c}$ \\
\hline
\end{tabular}

Serum levels of estrogen, $\mathrm{LH}$ and FSH were measured at the end of the treatment period. Values with different letters $(\mathrm{a}, \mathrm{b}, \mathrm{c}, \mathrm{d})$ are significantly different from one another (one-way ANOVA followed by Newman-Keuls multiple range test, $P<0.05$ ).

the herbal formula HPC 03 is a candidate for novel menopause therapies. HPC 03 is an herbal formula containing extracts of $A$. gigas, $C$. officinale Makino and $C$. cassia Presl. as the main ingredients. Although the effects of the individual medicinal herbs have been previously reported (Choi et al. 2012, de la Cruz et al. 2014, Sun et al. 2016), it is the first to report the effects of this herbal formula HPC 03. This study aimed to clarify the effects of HPC 03 in the estrogenic potential in vitro and in vivo.

Estrogens are known stimulants of cellular proliferation (Soto et al. 1995, Lee et al. 2012, Resende et al. 2013). The proliferation induced by HPC 03 was blocked by the addition of tamoxifen, an estrogen antagonist. These results indicated that HPC 03 was the estrogen-like physiological action. Estrogen and ERs are involved in the physiological function and regulation of the female reproductive system. Under physiological conditions, the biological effects of estrogen depend on not only the level of estrogen, but also the distribution and expression levels of the corresponding ERs in the target cell, ER $\alpha$ and ERß (Nagaraj \& Ma 2015, Warner et al. 2017). As the first step in the activation of ERs involves the binding of a ligand, the measurement of ligand binding is important in the characterization of the potential estrogenicity of test materials. Based on data, HPC 03 was thought to bind to ERs by the displacement of E2 binding. The binding of estrogens or selective estrogen-receptor modulators to ERs initiates a molecular signaling cascade that results in the transcriptional regulation of specific genes and protein synthesis (Lee et al. 2012, Nagaraj \& Ma 2015). Finally, the expression of estrogen-related genes may indicate the presence of a functional estrogen signaling pathway (Mestries et al. 1997, Jorgensen et al. 2000, Mueller 2002).
Upregulation of the expression of endogenous genes Psen2, Pgr and PTGES in MCF-7 cells is indicative of estrogenic effects via ER. In addition to Psen2, mRNA expression of the Pgr, Ctsd and PTGES genes in MCF-7 cells are also regulated in a characteristic manner by estrogenic compounds (Stossi et al. 2004, Chang et al. 2006). HPC 03 induced mRNA production of all three genes, suggesting that in MCF-7 cells, this herbal formula may act as estrogen agonists.

Ovariectomy is a widely used standard surgical procedure for the study of menopausal symptoms and postmenopausal osteoporosis, because OVX animals are characterized by reduced ovarian function, bone mass and strength (Xu et al. 2016, Garcia et al. 2017). The success of ovariectomy was also confirmed by examining the serum estradiol level. The serum estradiol levels were markedly decreased in all OVX rats and provided evidence of the success of the ovariectomy. OVX showed a significant 2-fold decrease on serum of estrogen compared with SHAM. This is similar to that observed in previous researches (Sharkey et al. 1998, Kang et al. 2016, Lee et al. 2016a). Estrogen, a reproductive hormone, is important in the maintenance of body weight, and estrogen deficiency following menopause is a serious cause of obesity in females. Thus, it is important to inhibit body weight gain to maintain the health of postmenopausal women (Roberts \& Hickey 2016). In our research, OVX showed a significant increase in body weight, which was also observed in other studies in comparison with the SHAM. However, HPC 03 resulted in a significant decrease in body weight. Furthermore, HPC 03 also restored the uterine weight decrease observed following OVX. The present study showed that HPC 03 increased serum estrogen levels. This result suggested that HPC 03 may stimulate
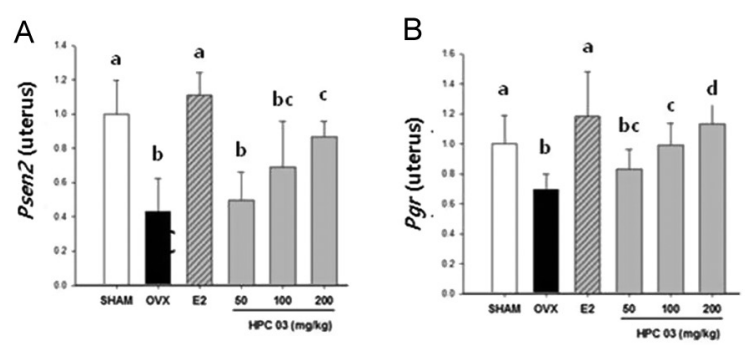

Figure 7 The effect of treatment with HPC 03 on mRNA expression of estrogen-dependent genes in the uterus of OVX rats. At the end of the treatment period, the uterus was separated and then the estrogen-dependent genes were determined. mRNA levels of (A) pS2, (B) PR and $(C)$ cathepsin $D$ were quantified using real-time PCR in uterus. The results are presented as the mean \pm S.D. Values with different letters (a, b, c, d) are significantly different one from another (one-way ANOVA followed by Newman-Keuls multiple range test, $P<0.05)$. 
the biosynthesis of estrogen. The serum levels of $\mathrm{LH}$ and FSH are a marker of the estrogenic effect (Cheng \& Tian 2012, Santoro et al. 2016). Also, HPC 03-treated group produced estrogen-mediated changes in $\mathrm{pS} 2$ and $\mathrm{PR}$ mRNA levels in uterus tissue of OVX group.

Bone loss caused by estrogen deficiency in both humans and experimental animals occurs primarily through an increase in osteoclastic bone resorption (Nishizawa et al. 2005, Varela et al. 2017). OVX rats, which exhibit most of the characteristics of human postmenopausal osteoporosis, have been widely used as a model for the evaluation of potential osteoporosis treatments (Ardawi et al. 2016, Xiao et al. 2016). OVX rats experienced a significant decrease in the femur BMD after 8 weeks. This BMD loss was accompanied by a significant increase in bone remodeling, which was evidenced by an enhanced bone turnover markers. An increase in ALP and BALP serum levels, the most widely used biochemical bone turnover markers, was observed in OVX rats (Hou et al. 2012). Furthermore, an increase in the serum levels of telopeptides of CTx, which correlates with high levels of bone resorption that indicates excessive osteoclastic activity and bone formation marker OC, were observed in OVX rats, and these results were supported by Lim and coworkers (Lim et al. 2014). A 12-week treatment with HPC 03 significantly decreased the BMD loss in the femur, which was reflected by the decrease in ALP, BALP, CTX and OC serum levels compared with the OVX: this effect may have resulted from decreased bone resorption (Abuohashish et al. 2015). Therefore, HPC 03 appears to be very effective for the inhibition of bone resorption and improvement in bone formation.

In conclusion, HPC 03 enhanced the cell growth and the estrogen-dependent genes such as Psen2, Pgr and Ctsd and stimulated proliferation of ER-positive MCF-7 cells.. HPC 03 attenuates bone loss, uterine atrophy and estrogen depletion in ovariectomized rats. It is thus expected that the HPC 03 may work as a new potent protective agent for relieving especially in terms of hormone imbalance and osteoporosis in menopausal women.

\section{Declaration of interest}

The authors declare that there is no conflict of interest that could be perceived as prejudicing the impartiality of the research reported.

\section{Funding}

This research was supported by the Ministry of Trade, Industry \& Energy (MOTIE), Korea Institute for Advancement of Technology (KIAT) through the Encouragement Program for The Industries of Economic Cooperation Region.

\section{Author contribution statement}

All authors read and approved the final version of the manuscript. S Y K conceived and designed the experiments. B Y C and D E K performed the experiments. B Y C, D E K and H S K analyzed the data. S Y K and B Y C drafted the manuscript. B Y C, D E K, H S K and S Y K revised the manuscript.

\section{References}

Abuohashish HM, Ahmed MM, Al-Rejaie SS \& Eltahir KE 2015 The antidepressant bupropion exerts alleviating properties in an ovariectomized osteoporotic rat model. Acta Pharmacologica Sinica 36 209-220. (https://doi.org/10.1038/aps.2014.111)

Anagnostis P, Karras S, Lambrinoudaki I, Stevenson JC \& Goulis DG 2016 Lipoprotein(a) in postmenopausal women: assessment of cardiovascular risk and therapeutic options. International Journal of Clinical Practice $\mathbf{7 0}$ 967-977. (https://doi.org/10.1111/ijcp.12903)

Ardawi MS, Badawoud MH, Hassan SM, Rouzi AA, Ardawi JM, AINosani NM, Qari MH \& Mousa SA 2016 Lycopene treatment against loss of bone mass, microarchitecture and strength in relation to regulatory mechanisms in a postmenopausal osteoporosis model. Bone 83 127-140. (https://doi.org/10.1016/j.bone.2015.10.017)

Asif M 2012 Phytochemical study of polyphenols in Perilla Frutescens as an antioxidant. Avicenna Journal of Phytomedicine 2 169-178.

Borrelli F \& Ernst E 2008 Black cohosh (Cimicifuga racemosa) for menopausal symptoms: a systematic review of its efficacy. Pharmacological Research 58 8-14. (https://doi.org/10.1016/j.phrs.2008.05.008)

Chang EC, Frasor J, Komm B \& Katzenellenbogen BS 2006 Impact of estrogen receptor beta on gene networks regulated by estrogen receptor alpha in breast cancer cells. Endocrinology 147 4831-4842. (https://doi. org/10.1210/en.2006-0563)

Chang A, Kwak BY, Yi K \& Kim JS 2012 The effect of herbal extract (EstroG-100) on pre-, peri- and post-menopausal women: a randomized double-blind, placebo-controlled study. Phytotherapy Research 26 510-516. (https://doi.org/10.1002/ptr.3597)

Chen Q, Shou P, Zhang L, Xu C, Zheng C, Han Y, Li W, Huang Y, Zhang X, Shao C et al. 2014 An osteopontin-integrin interaction plays a critical role in directing adipogenesis and osteogenesis by mesenchymal stem cells. Stem Cells 32 327-337. (https://doi.org/10.1002/stem.1567)

Cheng K \& Tian SL 2012 Effects of preventive-electroacupuncture of 'Guanyuan' (CV 4) and 'Sanyinjiao' (SP 6) on hypothalamus-pituitaryovary axis in ovariectomized rats. Zhen Ci Yan Jiu 3745.

Choi KO, Lee I, Paik SY, Kim DE, Lim JD, Kang WS \& Ko S 2012 Ultrafine Angelica gigas powder normalizes ovarian hormone levels and has antiosteoporosis properties in ovariectomized rats: particle size effect. Journal of Medicinal Food 15 863-872. (https://doi.org/10.1089/ jmf.2011.2047)

Conte Neto N, de Andrade CR, Spolidorio LC, Planeta Cda S, Cruz FC, de Souza Bastos A \& Marcantonio E Jr 2014 Effects of chronic stress and alendronate therapy on the osseointegration of titanium implants. Clinical Implant Dentistry and Related Research 16 762-771. (https:// doi.org/10.1111/cid.12046)

de la Cruz J, Kim DH \& Hwang SG 2014 Anti cancer effects of Cnidium officinale Makino extract mediated through apoptosis and cell cycle arrest in the HT-29 human colorectal cancer cell line. Asian Pacific Journal of Cancer Prevention 15 5117-5121. (https://doi.org/10.7314/ APJCP.2014.15.13.5117)

Dittfeld A, Koszowska A, Bronczyk AP, Nowak J, Gwizdek K \& Zubelewicz-Szkodzinska B 2015 Phytoestrogens - whether can they be an alternative to hormone replacement therapy for women during menopause period?. Wiadomosci Lekarskie 68 163-167.

Franco OH, Chowdhury R, Troup J, Voortman T, Kunutsor S, Kavousi M, Oliver-Williams C \& Muka T 2016 Use of plant-based therapies and menopausal symptoms: a systematic review and meta-analysis. JAMA 315 2554-2563. (https://doi.org/10.1001/jama.2016.8012)

Garcia AN, Bezner K, Depena C, Yin W \& Gore AC 2017 The effects of long-term estradiol treatment on social behavior and gene expression in adult female rats. Hormones and Behavior 87 145-154. (https://doi. org/10.1016/j.yhbeh.2016.11.011) 
Hill DA, Crider M \& Hill SR 2016 Hormone therapy and other treatments for symptoms of menopause. American Family Physician 94 884-889.

Hiruma W, Suruga K, Kadokura K, Tomita T, Sekino Y, Komatsu Y, Kimura M \& Ono N 2013 Antitumor effects of a plant extract mixture. Yakugaku Zasshi 133 487-491. (https://doi.org/10.1248/yakushi.12-00278-1)

Hou JM, Xue Y \& Lin QM 2012 Bovine lactoferrin improves bone mass and microstructure in ovariectomized rats via OPG/RANKL/RANK pathway. Acta Pharmacologica Sinica 33 1277-1284. (https://doi.org/10.1038/ aps.2012.83)

Huntley AL \& Ernst E 2003 A systematic review of herbal medicinal products for the treatment of menopausal symptoms. Menopause $\mathbf{1 0}$ 465-476. (https://doi.org/10.1097/01.GME.0000058147.24036.B0)

Jorgensen M, Vendelbo B, Skakkebaek NE \& Leffers H 2000 Assaying estrogenicity by quantitating the expression levels of endogenous estrogen-regulated genes. Environmental Health Perspectives 108 403-412. (https://doi.org/10.1289/ehp.00108403)

Kang SJ, Choi BR, Kim SH, Yi HY, Park HR, Song CH, Ku SK \& Lee YJ 2016 Selection of the optimal herbal compositions of red clover and pomegranate according to their protective effect against climacteric symptoms in ovariectomized mice. Nutrients 8. (https://doi.org/10.3390/ nu8080447)

Lee YM, Kim JB, Bae JH, Lee JS, Kim PS, Jang HH \& Kim HR 2012 Estrogenlike activity of aqueous extract from Agrimonia pilosa Ledeb. in MCF-7 cells. BMC Complementary and Alternative Medicine 12 260. (https:// doi.org/10.1186/1472-6882-12-S1-P260)

Lee KE, Shin JA, Hong IS, Cho NP \& Cho SD 2013 Effect of methanol extracts of Cnidium officinale Makino and Capsella bursa-pastoris on the apoptosis of HSC-2 human oral cancer cells. Experimental and Therapeutic Medicine 5 789-792. (https://doi.org/10.3892/ etm.2012.871)

Lee G, Choi CY \& Jun W 2016a Effects of aqueous extracts of cynanchum wilfordii in rat models for postmenopausal hot flush. Preventive Nutrition and Food Science 21 373-377. (https://doi.org/10.3746/ pnf.2016.21.4.373)

Lee WS, Shin JS, Jang DS \& Lee KT 2016b Cnidilide, an alkylphthalide isolated from the roots of Cnidium officinale, suppresses LPS-induced NO, PGE2, IL-1beta, IL-6 and TNF-alpha production by AP-1 and NF-kappaB inactivation in RAW 264.7 macrophages. International Immunopharmacology $40 \quad 146-155 . \quad$ (https://doi.org/10.1016/j. intimp.2016.08.021)

Leon A, Del-Angel M, Avila JL \& Delgado G 2017 Phthalides: distribution in nature, chemical reactivity, synthesis, and biological activity. Progress in the Chemistry of Organic Natural Products 104 127-246. (https://doi. org/10.1007/978-3-319-45618-8_2)

Lim DW, Lee Y \& Kim YT 2014 Preventive effects of Citrus unshiu peel extracts on bone and lipid metabolism in OVX rats. Molecules 19 783-794. (https://doi.org/10.3390/molecules19010783)

Mestries P, Kern P \& Avramoglou T 1997 Interactions between biospecific polymers and MCF7 cells: modulation of cellular proliferation and expression of estrogen receptors. Bulletin du Cancer 84 1017-1023.

Mueller SO 2002 Overview of in vitro tools to assess the estrogenic and antiestrogenic activity of phytoestrogens. Journal of Chromatography B: Analytical Technologies in the Biomedical and Life Sciences 777 155-165. (https://doi.org/10.1016/S1570-0232(02)00282-9)

Nagaraj G \& Ma C 2015 Revisiting the estrogen receptor pathway and its role in endocrine therapy for postmenopausal women with estrogen receptor-positive metastatic breast cancer. Breast Cancer Research and Treatment 150 231-242. (https://doi.org/10.1007/s10549-015-3316-4)

Nishizawa Y, Nakamura T, Ohta H, Kushida K, Gorai I, Shiraki M, Fukunaga M, Hosoi T, Miki T, Chaki O et al. 2005 Guidelines for the use of biochemical markers of bone turnover in osteoporosis (2004). Journal of Bone and Mineral Metabolism 23 97-104. (https://doi.org/10.1007/ s00774-004-0547-6)

Pfaffl MW 2001 A new mathematical model for relative quantification in real-time RT-PCR. Nucleic Acids Research 29 e45. (https://doi. org/10.1093/nar/29.9.e45)

Resende FA, de Oliveira AP, de Camargo MS, Vilegas W \& Varanda EA 2013 Evaluation of estrogenic potential of flavonoids using a recombinant yeast strain and MCF7/BUS cell proliferation assay. PLOS ONE 8 e74881. (https://doi.org/10.1371/journal.pone.0074881)

Roberts H \& Hickey M 2016 Managing the menopause: an update. Maturitas 86 53-58. (https://doi.org/10.1016/j.maturitas.2016.01.007)
Ross SM 2014 Efficacy of a standardized isopropanolic black cohosh (Actaea racemosa) extract in treatment of uterine fibroids in comparison with tibolone among patients with menopausal symptoms. Holistic Nursing Practice 28 386-391. (https://doi.org/10.1097/ HNP.0000000000000055)

Sagar T, Rantlha M, Kruger MC, Coetzee M \& Deepak V 2016 Ferulic acid impairs osteoclast fusion and exacerbates survival of mature osteoclasts. Cytotechnology 68 1963-1972. (https://doi.org/10.1007/s10616-0160009-8)

Santoro N, Worsley R, Miller KK, Parish SJ \& Davis SR 2016 Role of estrogens and estrogen-like compounds in female sexual function and dysfunction. Journal of Sexual Medicine 13 305-316. (https://doi. org/10.1016/j.jsxm.2015.11.015)

Satoh H 2013 Pharmacological characteristics of Kampo medicine as a mixture of constituents and ingredients. Journal of Integrative Medicine 11 11-16. (https://doi.org/10.3736/jintegrmed2013003)

Sewani-Rusike CR, Ralebona N \& Nkeh-Chungag BN 2016 Dose- and timedependent effects of Garcinia kola seed extract on sexual behaviour and reproductive parameters in male Wistar rats. Andrologia 48 300-307. (https://doi.org/10.1111/and.12447)

Sharkey LC, Holycross BJ, Park S, McCune SA, Hoversland R \& Radin MJ 1998 Effect of ovariectomy in heart failure-prone SHHF/Mcc-facp rats. American Journal of Physiology 275 R1968-R1976. (https://doi. org/10.1006/jmcc.1999.0985)

Shelton KA, Cline JM \& Cann JA 2013 17-beta Estradiol reduces atherosclerosis without exacerbating lupus in ovariectomized systemic lupus erythematosus-susceptible LDLr(-/-) mice. Atherosclerosis 227 228-235. (https://doi.org/10.1016/j.atherosclerosis.2012.12.031)

Soto AM, Sonnenschein C, Chung KL, Fernandez MF, Olea $\mathbf{N}$ \& Serrano FO 1995 The E-SCREEN assay as a tool to identify estrogens: an update on estrogenic environmental pollutants. Environmental Health Perspectives 103 (Supplement 7) 113-122. (https://doi.org/10.1289/ ehp.95103s7113)

Stossi F, Barnett DH, Frasor J, Komm B, Lyttle CR \& Katzenellenbogen BS 2004 Transcriptional profiling of estrogen-regulated gene expression via estrogen receptor (ER) alpha or ERbeta in human osteosarcoma cells: distinct and common target genes for these receptors. Endocrinology 145 3473-3486. (https://doi.org/10.1210/en.2003-1682)

Sun L, Zong SB, Li JC, Lv YZ, Liu LN, Wang ZZ, Zhou J, Cao L, Kou JP \& Xiao W 2016 The essential oil from the twigs of Cinnamomum cassia Presl alleviates pain and inflammation in mice. Journal of Ethnopharmacology 194 904-912. (https://doi.org/10.1016/j.jep.2016.10.064)

Takakura A, Lee JW, Hirano K, Isogai Y, Ishizuya T, Takao-Kawabata R \& limura T 2017 Administration frequency as well as dosage of PTH are associated with development of cortical porosity in ovariectomized rats. Bone Research 5 17002. (https://doi.org/10.1038/boneres.2017.2)

Taylor M 2015 Complementary and alternative approaches to menopause. Endocrinology Metabolism Clinics of North America 44 619-648. (https://doi.org/10.1016/j.ecl.2015.05.008)

Tomaz LM, Barbosa MR, Farahnak Z, Lagoeiro CG, Magosso NS, Lavoie JM \& Perez SE 2016 GLUT2 proteins and PPARgamma transcripts levels are increased in liver of ovariectomized rats: reversal effects of resistance training. Journal of Exercise Nutrition and Biochemistry 20 51-57. (https://doi.org/10.20463/jenb.2016.06.20.2.7)

Varela A, Chouinard L, Lesage E, Smith SY \& Hattersley G 2017 One year of abaloparatide, a selective activator of the PTH1 receptor, increased bone formation and bone mass in osteopenic ovariectomized rats without increasing bone resorption. Journal of Bone and Mineral Research 32 24-33. (https://doi.org/10.1002/jbmr.3003)

Warner M, Huang B \& Gustafsson JA 2017 Estrogen receptor beta as a pharmaceutical target. Trends in Pharmacological Sciences 38 92-99. (https://doi.org/10.1016/j.tips.2016.10.006)

Wei QS, Huang L, Chen XH, Wang HB, Sun WS, Huo SC, Li ZQ \& Deng WM 2014 Effect of whole body vibration therapy on circulating serotonin levels in an ovariectomized rat model of osteoporosis. Iranian Journal of Basic Medical Sciences 17 62-68.

Xiao YP, Tian FM, Dai MW, Wang WY, Shao LT \& Zhang L 2016 Are estrogenrelated drugs new alternatives for the management of osteoarthritis? Arthritis Research and Therapy 18 151. (https://doi.org/10.1186/s13075016-1045-7)

Xu JH, Yao M, Ye J, Wang GD, Wang J, Cui XJ \& Mo W 2016 Bone mass improved effect of icariin for postmenopausal osteoporosis in ovariectomy- 
induced rats: a meta-analysis and systematic review. Menopause 23 1152-1157. (https://doi.org/10.1097/GME.0000000000000673)

Zhang CG, Zhang B, Deng WS, Duan M, Chen W \& Wu ZY 2016 Role of estrogen receptor beta selective agonist in ameliorating portal hypertension in rats with $\mathrm{CCl} 4$-induced liver cirrhosis. World Journal of Gastroenterology 22 4484-4500. (https://doi.org/10.3748/wjg.v22. i18.4484)

Zhao B, Wang Q, Tao T, Li J \& Lin Q 2013 The in vitro and in vivo treatment effects of overexpressed lentiviral vector-mediated human BMP2 gene in the femoral bone marrow stromal cells of osteoporotic rats. International Journal of Molecular Medicine 32 1355-1365. (https://doi.org/10.3892/ ijmm.2013.1507)
Zhu X, Liew Y \& Liu ZL 2016 Chinese herbal medicine for menopausal symptoms. Cochrane Database of Systematic Reviews 3 Cd009023. (https://doi.org/10.1002/14651858)

Received 29 August 2017

First decision 13 September 2017

Revised manuscript received 29 October 2017

Accepted 3 November 2017 